\title{
Pengaruh Sistem Hukum Common Law Terhadap Kontrak Bisnis Modern Di Indonesia
}

\author{
Della Arrilia \\ Magister Kenotariatan, Fakultas Hukum, Universitas Surabaya
}

\begin{tabular}{|c|c|}
\hline Article Info & Abstrak \\
\hline Article history: & $\begin{array}{l}\text { Penelitian ini bertujuan untuk: (1) menghasilkan media pembelajaran } \\
\text { multimedia interaktif biologi berbasis SAVI (Somatic, Auditory, Visual, }\end{array}$ \\
\hline Article Reseived: 22 July 2021 & Intelectual) materi pembelajaran monera; (2) mengetahui tingkat kelayakan \\
\hline Publication: 23 July 2021 & multimedia interaktif biologi berbasis SAVI yang telah dikembangkan. \\
\hline Kata Kunci: & model ADDIE. Penelitian ini hanya menggunakan 3 tahap pengembangan yaitu \\
\hline $\begin{array}{l}\text { Common Law, Kontrak Bisnis, } \\
\text { Klausula Baku. }\end{array}$ & $\begin{array}{l}\text { analysis, design, dan develop. Hasil validasi menunjukkan bahwa media } \\
\text { pembelajaran multimedia interaktif biologi berbasis SAVI sangat layak } \\
\text { digunakan pada materi pembelajaran monera. }\end{array}$ \\
\hline
\end{tabular}

This is an open access article under the Lisensi Creative Commons Atribusi-BerbagiSerupa 4.0 Internasional

Corresponding Author:

Della Arrilia

Magister Kenotariatan, Fakultas Hukum, Universitas Surabaya

Email:dellaarrilia1@gmail.com

\section{PENDAHULUAN}

Indonesia sebagai sebuah negara hukum menganut sistem hukum yang dipengaruhi negara penjajah, yaitu Belanda yang menganut sistem hukum Eropa Kontinental atau Civil Law Sistem. Sampai kemudian dalam perkembangan dewasa ini, sistem hukum Indonesia perlahan mulai dipengaruhi common law sistem. Hal tersebut sudah tidak dapat dihindari, mengingat dinamika globalisasi yang menghapus segala batas dan kendala di antara negara-negara di dunia. Kondisi tersebut mempermudah dan memperbanyak terjadinya hubungan-hubungan antar tata hukum.

Pengejawantahannya dapat dilihat secara nyata dengan jamaknya konvensi tingkat internasional yang diadakan dan diikuti oleh banyak negara dengan sistem hukum yang berbeda. Hasil dari konvensi-konvensi tersebut harus diratifikasi sebagai bentuk iktikad baik negara-negara yang telah menandatanganinya.

Ratifikasi atas berbagai konvensi yang kemudian ditindaklanjuti dengan penyusunan peraturan perundang-undangan di masing-masing negara berdasarkan hasil konvensi dan kepentingan negara masing-masing jelas akan mempengaruhi sistem hukum yang satu dengan sistem hukum lainnya. Belum lagi adanya kontribusi dari penandatanganan perjanjian bilateral maupun multilateral antar negara.

Menurut Black's law Dictionary (H. Campbell, 1999) kontrak adalah:

"An agreement between two or more parties creating obligation that are enforceable or otherwise recognizable at law”.

Suatu kesepakatan atau perjanjian antara dua pihak atau lebih yang menciptakan kewajiban yang dapat dilaksanakan atau dapat dikenali secara hukum. 
Sedangkan yang dimaksud dengan hukum kontrak adalah mekanisme hukum dalam masayarakat untuk melindungi harapan-harapan yang timbul dalam pembuatan persetujuan demi perubahan masa datang yang bervariasi kinerja, seperti pengangkutan kekayaan, kinerja pelayanan, dan pembayaran dengan uang (Salim HS, 2004).

Sejumlah konvensi, perjanjian bilateral maupun multilateral, membawa dampak yang signifikan dalam perkembangan dan pembangunan sistem hukum di Indonesia. Pengaruhnya dimulai pada saat minyak menjadi komoditas yang paling dicari di Indonesia pada periode 1970an. Ketika itu, Indonesia yang diwakili oleh Pertamina mulai mengadakan hubungan hukum (kontrak bisnis) dengan negara-negara lain, baik dalam kapasitas sebagai negara pembeli minyak, maupun sebagai negara/perusahaan yang mengeksplorasi ladang-ladang minyak. Secara langsung maupun tidak langsung, banyak kontrak bisnis yang berlangsung saat itu adalah kontrak bisnis yang dilakukan dengan negara yang menganut sistem common law.

Setelah melewati fase booming minyak tadi, Indonesia mulai dijadikan sebagai salah satu dari negara dunia ketiga yang menjadi negara tujuan investasi dari banyak negara maju di dunia. Kebijakan investasi pintu terbuka yang diambil selama orde baru mengakibatkan investasi asing mengalir sedemikian derasnya. Namun di sisi lain, kontrak-kontrak bisnis secara bertubi-tubi juga mulai banyak terjadi.

Investasi yang terus masuk tentunya diikuti dengan dibuatnya kontrak-kontrak bisnis. Kontrak-kontrak bisnis yang diadakan (baik Government to Government, maupun Business to Business) lazimnya diikuti dengan standard clause yang baku dan bersifat memaksa kepada pihak yang lainnya. Penelitian ini akan membahas secara mendalam mengenai pengaruh sistem hukum common law terhadap sistem hukum dan kontrak-kontrak bisnis di Indonesia, serta implikasi standard clause terhadap konsensualisme perjanjian dan pelaksanaan perjanjian.

\section{HASIL PENELITIAN DAN PEMBAHASAN}

Sistem hukum Common Law, menurut Black's Law Dictionary (Henry Campbell, 1999) adalah:

"The body of law derived from judicial decisions rather than from statutes or constitutions".

Kumpulan atau sistem hukum yang bersumber dari keputusan pengadilan dibanding/bukannya dari undang-undang/anggaran dasar atau konstitusi.

Sejarah perkembangan common law system pada awalnya berkembang dalam sejarah sistem hukum Inggris sekitar tahun $1066 \mathrm{M}$, yang berkembang dengan didasarkan pada tradisi, kebiasaan, dan bentuk-bentuk keputusan yang ada. Dalam terjemahan bebas berarti sistem hukum common law berkembang dalam sejarah Inggris dari putusan hukum yang berdasarkan tradisi, kebiasaaan dan preseden. Bentuk dari alasan penggunaan sistem ini adalah kasuistik.

David dan Bierly (Salim HS, 2004) membagi periodisasi Common Law ke dalam beberapa tahapan:

1. Sebelum penaklukan Norman di tahun 1066

2. Periode kedua membentang dari 1066 sampai ke Penggabungan Tudors (1485). Selama periode ini berlangsung pembentukan common law, yaitu penerapan sistem hukum tersebut secara luas dengan menyisihkan kaidah-kaidah lokal.

3. Tahun 1485 sampai 1832. Dalam periode ini berkembang suatu sistem kaidah lain yang disebut "kaidah equity". Sistem kaidah ini berkembang di samping common law dengan fungsi melengkapi dan pada waktu-waktu tertentu juga menyaingi common law.

4. Dari tahun 1832 sampai sekarang. Ini merupakan periode modern bagi common law. Periode ini menunjukkan perkembangan dalam penggunaan hukum yang dibuat atau perundangundangan. Tidak bisa lagi hanya mengandalkan perkembangan yang bersifat tradisional. Untuk menghadapi kehidupan modern, common law semakin menerima campur tangan pemerintah dan badan-badan administrasi. 


\subsection{SEJARAH PERKEMBANGAN KONTRAK BISNIS}

Menurut Munir Fuady (2003) sejarah hukum kontrak di Inggris lebih dapat dilaksanakan oleh pengadilan-pengadilan lain yang saling berkompetisi selain pengadilan common law yaitu oleh pengadilan-pengadilan sebagai berikut :

a. Oleh pengadilan yang mengadili kasus-kasus hukum dagang (law of merchant)

b. Oleh pengadilan gereja (church court) terutama terhadap kontrak yang disumpah (sworn promise) dengan memakai hukum gereja (canon law)

c. Oleh pengadilan equity yang dilaksanakan chancellor dengan memakai hukum equity.

Salah satu fenomena yang sangat menonjol dalam hukum Inggris seperti juga dalam sistem hukum anglo saxon adalah begitu dominannya pengaruh dari teori ekuivalensi dalam suatu- kontrak, sehingga dalam setiap kontrak, kedua pihak harus berprestasi. Kontrak dengan prestasi hanya satu pihak, seperti hibah, belum dianggap kontrak yang sempurna (Munir Fuady, 2003).

Selain itu Munir Fuady (2003) menyatakan ditinjau dari sudut pandang keseimbangan prestasi dalam suatu kontrak, maka hukum Inggris mengenal 4 macam kontrak sebagai berikut

a. Pengakuan hutang dengan seal. Model kontrak hutang seperti ini dianggap sepenuhnya mengandung prestasi yang seimbang.

b. Convenant atau undertaking dengan seal Karena ada seal maka dianggap bahwa kontrak tersebut mengandung contra prestasi yang layak.

c. Kontrak hutang yang nyata Dalam hal ini keterikatan timbul dengan adanya penguasaan atas benda tertentu yang telah diserahkan kepadanya oleh pihak lain.

d. Kontrak sederhana dengan prestasi di kedua belah pihak.

Dalam hal ini kedua belah pihak berprestasi dan para pihak terikat karena mengasumsi kewajibannya dengan imbalan contra prestasi dari pihak lainnya.

Hukum kontrak di Amerika mengikuti hukum kontrak di Inggris. Bahkan hukum kontrak diangggap sebagai bidang hukum yang sangat common law oriented, sehinggga tidak banyak aturan yang dibuat untuk bidang kontrak ini. Karena itu, setiap kaidah hukum kontrak yang ada dalam sejarah hukum Inggris di praktekkan di Amerika Serikat. Putusan pengadilan di Amerika Serikat seringkali mengacu kepada kasus-kasus yang terjadi di Inggris Raya (Munir Fuady, 2003).

Munir Fuady (2003) menjelaskan perkembangan hukum kontrak di Amerika Serikat mulai terjadi pada awal abad ke-19, bahkan abad ke 19 di anggap sebagai jaman keemasan (golden age) bagi hukum kontrak, sehingga dapat dikatakan bahwa abad ke-19 adalah abad kontrak di Amerika Serikat.

Dari segi sejarah. perundang-undangan yang berkenaan dengan kontrak, suatu perkembangan yang monumental adalah dengan dikeluarkannya di Amerika Serikat suatu undang-undang yang disebut dengan Uniform Sale Act pada tahun 1906, dan Uniform conditional Sale Act dalam tahun 1918. Kemudian, meaterinya, bersama-sama dengan mated dari beberapa ketentuan perundang-undangan lainnya digabung dalam suatu undang-undang yang Seragam yang cukup popular, yaitu apa yang disebut dengan Uniform Commercial Code, dimana tentang jual beli diatur dalam artikel 2. Teks resmi dari Uniform Commercial Code ini yang pertama sekali: keluar adalah teks resmi tahun 1962 (Munir Fuady, 2003).

Selain itu Munir Fuady (2003) menambahkan prinsip kebebasan berkontrak dianut bangsa Amerika Serikat sejak dikumandangkan pertama kalinya oleh Adam Smith, bahkan sampai diakui dalam konstitusi Amerika Serikat, dengan dilarangnya negara untuk membatalkan atau ikut campur dalam kontrak yang dihuat oleh warga negara. Inilah yang disebut dengan doktrin "contract clause" yang sering menjadi bahan kajian bagi hukum tata negara Amerika Serikat (Munir Fuady, 2003).

Hukum kontrak di Indonesia sebenarnya sudah dilaksanakan sejak hukum adat diberlakukan sebagai hukum. Kontrak yanc paling meluas dilakukan dlam hukum adat tentu 
kontrak jual beli, tetapi tempo dulu sebelum mata uang meluas dipakai, kontrak tukaar menukarlah yang banyak dilakukan, misalnya para petani membawa hasil pertaniannya ke pasar untuk ditukar dengan barang-barang keperluan rumah tangga lainya (Munir Fuady, 2003).

Pada prinsipnya menurut Munir Fuady (2003) hukum kontrak yang berkembang baik dalam hukum adat dan terkeam secara meluas adalah kontrak yang berkenaan dengan tanah, sedangkan kontrak yang bukan mengenai tanah banyak terjadi antara lain dibidang hukum perkawinan dan keluarga, hibah, hibah wasiat, hutang-piutang, pinjam-meminjam, tukarmenukar, jual-bali atau jaminan benda bergerak.

Sedangkan mengenai kontrak yang tidak ada hubungannya dengan tanah, kecuali kontrak dalam bidang hukum keluarga umumnya sudah tidak lagi menggunakan prinsip hukum adat tetapi oleh pengadilan maupun dalam praktek sehari-hari sudah menggunakan hukum kontrak dalam KUHPerdata Indonesia (terdapat dalam buku ketiga) (Munir Fuady, 2003).

Selanjutnya, dalam perkembangan dari hukum kontrak, asas kebebasan berkontrak banyak dibatasi oleh berbagai hal, antara lain oleh berbagai perundang-undangan yang berlaku. Misalnya, dengan keluarnya Undang-Undang Nomor 5 Tahun 1999 Tentang Larangan Praktek Monopoli dan Persaingan Tidak Sehat, maka banyak pembatasan yang diberikan kepada para pihak dalam membuat klausula-klausula dalam suatu kontrak perdagangan. Disamping itu, munculnya banyak kontrak baku (Standard Contract) juga menyebabkan banyak terjadi pembatasan terhadap azas kebebasan berkontrak, baik kontrak baku yang dibuat pemerintah maupun kontrak baku yang dibuat di antara sesama kalangan bisnis. Kontrak baku yang dibuat oleh pemerintah, misalnya berbagai formulir kontrak yang berkenaan dengan peralihan hak atas tanah, yang dikenal dengan akta pejabat pembuat akta tanah (akta PPAT). Sedangkan kontrak baku yang dibuat kalangan bisnis sangat banyak macamnya seperti polis asuransi, formulir perbankan, dan sebagainya.

Akhirnya kontrak-kontrak di Indonesia yang dipengaruhi oleh common law antara lain Franchise, Lisence, Joint venture, Loan Agreement, Technical Asisstance, Agency Agreement .

\subsection{PENGARUH COMMON LAW DALAM PERKEMBANGAN KONTRAK BISNIS DI INDONESIA}

Perkembangan Kontrak di Indonesia telah mengalami beberapa kemajuan yang cukup pesat, hal ini juga tidak terlepas dari perkembangan sector ekonomi khususnya bisnis yang memiliki kebutuhan besar akan sebuah kontrak. Selanjutnya penting kiranya mengetahui terlebih dahulu mengetahui awal perkembangan hukum di Indonesia. Sebagaimana kita ketahui Sistem hukum di Indonesia banyak di pengaruhi oleh sistem hukum civil law. Sistem hukum civil law ini sendiri berasal dari Perancis. Berdasarkan asas konkordansi, hukum yang berlaku di Nederland berlaku juga untuk Hindia Belanda, pada mulanya untuk orang-orang eropa. Hukum barat ini berlaku untuk golongan Timur Asing dan Bumi purra moialui penundukan diri secara sukarela maupun diam-diam (Natasya Y. Sugiastuti, 2004).

Selain itu menurut Natasya Y. Sugiastuti (2004) Common Law masuk di Indonesia tahun 1967 ditandai dengan masuknya modal asing, yang mana kebijakan tersebut sangat mempengaruhi keberadaan sistim hukum di Indonesia dengan masuknya sistem common law. Sistem ini berasal dari Inggris yang lahir pada masa pemerintahan Henrry II abad ke 13. Hakim di negara common law harus mengikuti keputusan-keputusan hakim yang terdahulu dalam perkara-perkara yang faktanya sama (stare decisis doct-rine).

Common law masuk ke Indonesia dengan herapa cara. Pertama melalui perjanjianperjanjian internasional di mana Indonesia menjadi anggotanya. Kodua, common law mempengaruhi Indonesia melalui kontrak-kontrak hisnis yang dibuat oleh kalangan swasta. Misalnya joint Venture Agreement, Franchise Agreement, Loan Agreement, Agency Agreement. Ketiga, datangnya ahli-ahli asing mengiringi bantuan luar negeri ke Indonesia telah turut mempercepat pengaruh common law di Indonesia. Hal ini seiring dengan keperluan Indonesia untuk menciptakan institusi-institusi keuangan yang baru, seperti pasar modal. Hal 
mana juga dengan banyak dipengaruhi melalui para sarjana hukum Indonesia yang banyak belajar di negara -negara common law seperti Amerika Serikat, Inggris dan Australia Natasya Y. Sugiastuti, 2004).

Apabila dibahas lebih lanjut mengenai kontrak-kontrak bisnis di Indonesia perlu dilihat pengertian dari Joint Venture Agreement, Franchise Agreement. Dalam Black's law Dictionary (Henry Campbell Black, 1999) Franchise Agreement sendiri mempunyai pengertian sebagai berikut :

"The Contract between a franchisor and franchisee esthablishing the terms and condition of the franchise relationship. state and federal laws regulate franchise agreement".

Perjanjian antara pemegang hak waralaba dan penerima hak waralaba yang dibuat dengan kesepakatan dan kondisi dalam hubungan pemberian waralaba. Hukum negara yang mengatur perjanjian waralaba.

Selanjutnya Joint Venture Agreement dalam Black's law Dictionary (Henry Campbell Black, 1999) mempunyai pengertian:

"A business undertaking by two or more persons engaged in a single defined project. The necessary elements are (1) An express or impled agreement; (2) a common purpose that the group intends to carry out; (3) shared profits and losess; (4) each members equal voice in contrinlling the project. - also termed joint adventure; joint enterprises".

Bisnis yang dilakukan oleh dua orang atau lebiuh yang melaksanakan satu pekerjaan tertentu. Hal-hal penting yang berkaitar. (1) perjanjian yang dapat dilaksanakan; (2) tujuan umum yang dilakukan kelompok tersebut; (3) pembagian keuntungan atau kerugian; (4) setiap anggota memiliki hak suara yang sama dalam mengontrol pekerjaan. Juga disebut pekerjaan patungan; perusahaan patungan.

\subsection{IMPLIKASI KLAUSULA STANDAR TERHADAP KONSENSUALISME PERJANJIAN DAN PELAKSANAAN PERJANJIAN}

Standart Clausula atau perjanjian baku dilatar belakangi oleh keadaan sosial ekonomi. Dalam hal ini pihak yang posisi tawarnya lebih kuat menentukan isi dari kontrak yang disodorkan pada pihak lain yang lebih lemah posisinya, baik karena keadaan sosial ekonomi maupun karena ketidaktahuannya.

Dengan adanya perjanjian baku semacam ini memang pihak yang kuat, dalam hal ini biasanya adalah pihak pengusaha, dapat melakukan efisiensi waktu, biaya dan tenaga. Akan tetapi jenis perjanjian atau kontrak semacam ini memiliki kelemahan karena syarat-syarat yang ditentukan secara sepihak dan pihak lainnya terpaksa menerima keadaan itu tanpa ada kesempatan untuk melakukan perubahan.

Klausul eksonerasi atau perjanjian baku dapat dibedakan dalam tiga jenis (Mariam Darus Badrulzaman, 1994), yaitu sebagai berikut :

1. Perjanjian baku sepihak adalah perjanjian yang isinya ditentukan oleh pihak nyang kuat kedudukannya di dalam perjanjian itu. Pihak yang kuat disini adalah pihak kreditur yang lazimnya mempunyai posisi (ekonomi) yang kuat dibandingkan pihak debitur. Kedua pihak lazimnya terikat dalam organisasi, misainya perjanjian buruk kolektif.

2. Perjanjian baku yang dietetapkan pemerintah, ialah perjanjian baku yang mempunyai objek hak-hak atas tanah.

3. Perjanjian baku yang ditentukan di lingkungan notaris atau advokat terdapat perjanjianperjanjian yang konsepnya sejak semula sudah disediakan untuk memenuhi permintaan dari anggota masyarakat yang minta bantuan notaris atau advokat yang bersangkutan. Di dalam kepustakaan Belanda, jenis ini disebut contract model.

Dari keseluruhan jenis perjanjian baku ini, Mariam Darus Badrulzaman (1994) menyimpulkan bahwa ciri-ciri meniadakan dan membatasi kewajiban salah satu pihak (kreditur) untuk membayar ganti rugi kepada debitur adalah sebagai berikut: 
1. Isinya ditetapkan secara. sepihak oleh kreditur yang posisinya relatif lebih kuat dari debitur;

2. Debitur sama sekali tidak ikut menentukan isi perjanjian itu;

3. Terdorong oleh kebutuhannya debitur terpaksa menerima perjanjian itu;

4. Bentuknya tertulis;

5. Dipersiapkan terlebih dahulu secara massal atau individual.

Perjanjian standar oleh Pitlo dinamakan juga perjanjian adhesi. Pitlo mengemukakan perjanjian standar ini adalah suatu "dwangkoitract" karena kebebasan pihak-pihak yang dijamin Pasal 1338 KUH Perdata sudah dilanggar. Sedangkan pihak yang lemah terpaksa menerima hal ini sebab mereka tidak mampu berbuat lain (Hasanuddin Rahman, 2003).

Sedangkan dalam Pasal 1320 KUH Perdata disebutkan bahwa untuk sahnya suatu perjanjian diperlukan empat syarat :

1. Sepakat mereka yang mengikatkaa dirinya;

2. Kecakapan untuk membuat suatu perikatan;

3. Suatu hal tertentu;

4. Suatu sebab yang halal.

Dalam pasal ini memuat asas konsensualisme atau pacta sunt servanda atau kepakatan untuk mengikatkan diri.

Perjanjian/kontrak standar atau baku dapat saja menimbulkan hubungan yang berat sebelah dan keadaan yang tidak seimbang. Ketentuan dalam suatu perjanjian dapat menjadi tidak patut atau tidak adil bila perjanjian itu terbentuk pada suatu hubungan atau keadaan yang tidak seimbang. Bila ketidakpatutan itu terjadi pada hubungan para pihak tidak seimbang, maka keadaan ini dinamakan Undue Influence. Sedangkan bila ketidakadilan terjadi pada suatu keadaan (bukan hubungan) yang tidak seimbang, maka hal ini dinamakan unconscionability (Hasanuddin Rahman, 2003).

Undue Influence dipandang dari akibat ketidakseimbangan itu terhadap pemberian kesepakatan dari pihak yang dipengaruhi, sedangkan unconscionability dipandang dari kelakuan pihak yang kuat dalam usahanya memaksakan atau memanfaatkan.transaksinya terhadap orang yang lemah, apakah sesuai kepatutan (goog consience).

Kembali ke asas konsensualisme, maka dapat dikatakan bahwa standart clausula atau perjanjian baku secara teoritis tidak memenuhi asas konsensualisme yang berakibat pada tidak terpenuhinya asas kekuatan mengikat yang tercantum dalam Pasal 1338 KUH Perdata.

Perbedaan posisi para pihak ketika perjanjian baku diadakan tidak memberikan kesempatan pada debitur untuk, mengadakan perubahan terhadap isi perjanjian. Oleh karena itu hal ini tidak memenuhi elemen-elemen yang dikehendaki pasal 1320 jo. 1338 KUHPerdata, sehingga perjanjian ini tidak memiliki akibat.

\section{KESIMPULAN}

Pengaruh sistem hukum common law terhadap sistem hukum di Indonesia banyak berkaitan dengan kegiatan ekonomi, termasuk didalamnya kontrak-kontrak bisnis, pengambilan keputusan pengadilan juga ikut terpengarug dengan sistem hukum ini seperti arbitase dan peradiklan niaga dalam menyelesaikan sengketa-sengketa kontrak. Sedangkan terkait pengaruh common law dalam kontrak-kontrak bisnis di Indonesia, bisa dilihat dari pertama kali masuknya modal asing. Kedua, kontrak-kontrak bisnis yang dibuat oleh kalangan swasta, misalnya joint Venture Agreement, Franchise Agreement, Loan Agreement, Agency Agreement. Dan ketiga, para sarjana hukum Indonesia banyak yang belajar di negara-negara common law. Selanjutnya mengenai perjanjian baku, secara teoritis tidak memenuhi asas konsensualisme yang berakibat pada tidak terpenuhinya asas kekuatan mengikat sebagaimana Pasal 1338 KUH Perdata dan Impikasinya yaitu tidak terpenuhinya elemen-elemen yang dikehendaki Pasal 1320 Jo. Pasal 1338 KUHPerdata, sehingga perjanjian ini tidak memiliki akibat.

Rekomendasi yang dapat diberikan adalah sebaiknya Indonesia menyusun produk hukum yang secara spesifik memberikan aturan-aturan dasar yang harus diperhatikan apabila sesuatu 
pihak dalam suatu perjanjian menghendaki agar suatu klausul yang memberatkan dalam perjanjian baku berlaku bagi hubungan hukum antara pihaknya dengan mitra janjinya.

\section{DAFTAR PUSTAKA}

Badrulzaman, Mariam Darus. 1994. Aneka Hukum Bisnis. Bandung: Alumni.

Black, Henry Campbell. 1999. Black Law Dictionary, Seventh Edition. ST. Paul: West Group.

Fuady, Munir. 2003. Hukum Kontrak. Bandung: Citra Aditya Bakti.

Rahman, Hasanuddin. 2003. Contract Drafting. Bandung: Citra Aditya Bakti.

Salim HS. 2004. Hukum Kontrak Teori dan Tehnik Penyusunan Kontrak. Jakarta: Sinar Grafika. Sugiastuti, Natasya Y. 2004. Sejarah Hukum Civil Law-Common Law. Jakarta: FHUI. 